\title{
In Kind or Monetary Restitution? Historic Wrongs and Indigenous Land Claims
}

\author{
Scott Morrison ${ }^{1}$ \\ ${ }^{1}$ Akita University, Akita City, Japan \\ Correspondence: Scott Morrison, Akita University, Akita City, Japan. E-mail: smsmorrison@gmail.com
}

Received: March 12, 2014 Accepted: March 21, 2014 Online Published: May 28, 2014

doi:10.5539/jpl.v7n2p50 URL: http://dx.doi.org/10.5539/jpl.v7n2p50

\begin{abstract}
Native peoples in North America, Australia and New Zealand have (sometimes successfully) demanded compensation for seizures of their ancestral lands. This article sets out the arguments against restitution in these and other cases. It then offers up a defense of "in kind" restitution, that is, the return of lands or other property misappropriated. As a pertinent case study this article narrates the story of the Sioux tribes of the mid-western United States. They have sought to recover lands in and around the Black Hills of South Dakota. Offering a view of the historical and contemporary collective cultural and spiritual significance of the Black Hills and the history of dispossession therefrom, this article traces the Sioux's individual and tribal efforts both through the legal system and the courts and into the US federal government where a bill was unsuccessfully put forward in an effort to resolve their claims.
\end{abstract}

Keywords: Black Hills, historic wrongs, land claims, Native Americans, restitution, Sioux

\section{Introduction}

Aboriginal peoples in Canada, the US, Australia and New Zealand have -- throughout this century and with some success in recent years -- demanded reparation for historic injustices, such as unfair purchases and seizures of land. It is widely recognized by citizens and governments alike that such injustices have occurred, but it is often unclear what should be done in response. In sections 2 and 3 respectively I will criticize what I take to be the strongest arguments against restitution, arguments raised by Jeremy Waldron and Jon Elster, and I will argue that under certain conditions justice requires restitution.

I will argue further (in section 4) that in certain kinds of cases restitution must take the form of "in kind" restitution, that is, the return of what was taken. In this respect, I will be opposing US government policy which has generally permitted monetary rewards only. Although I will explicitly address land, some of the arguments I will make also apply to other material goods, including artifacts and art objects of various kinds, whether they were held individually or collectively; for example, paintings, and other art objects, or archeological finds taken during war or colonial periods.

In sections 5 and 6, I will apply and illustrate the theoretical claims of the first part, with reference to the ongoing case of the Sioux tribes, who have sought to recover lands in and around the Black Hills of South Dakota. With this application, I aim to make the issue of restitutive justice more vivid, and to draw attention to the policy issue involved in this and in other similar Native American land claims.

\section{2. "Superseding Historic Injustice"}

Jeremy Waldron (1992) advances two pragmatic and two principled objections to compensation for historic injustice. He observes that rights of various sorts are thought to fade over time. The reason entitlements to property or claims for restitution may be thought to fade, he suggests, are procedural and non-procedural. The procedural difficulty is that evidence and memory are lost over time, and it is difficult to establish the facts of what occurred. Non-procedurally, those who control a resource, however it may have been obtained, build expectations relying on it, organizing their lives around it. Disturbing these expectations, which, it can be added, could well have been formed without any knowledge of prior injustice, will be "costly and disruptive." (Waldron, 1992)

The first objection does not happen to be very compelling in many cases where courts (in the US and Canada, for example) have recognized that takings occurred, and have awarded money as a result. Of course, if the facts cannot be established and the legal tests satisfied, then there is no basis for a claim. Regarding the cost, it is true that 
successful claims for restitution cost the government and the taxpayers substantial sums, although it is difficult to see what further disruption would be entailed in cases of monetary restitution.

Further disruption will admittedly result from land or other property transfers; I will address the conditions which call for such transfers, even when further disruptions and costs of this sort will result. Any effort at achieving justice, or, for that matter, living a moral life, comes at a cost, but this does not lessen the desirability of working for justice, or living a moral life. Nevertheless, I will later suggest conditions under which obligations to recompense are limited or overridden -- not due to cost per se, but due to the present injustices which recompense would inflict.

One of the principled reasons Waldron presents is that there is not a definition of property rights which yields a lasting entitlement, one which is immune from fading over time. He posits an account of entitlement in which an individual or group who takes possession of land or some other property makes it part of their lives, upon which their thinking and planning and action rests. (1992: 18) I accept this account for lack of a better one, and agree that such an entitlement fades over time, but I deny that we require a conception of a lasting entitlement in order to justify restitution. What warrants compensation in the present is not the existence of an entitlement in the present, but rather the fact of past harm. The victims of a past injustice had a property right at the time of the taking, and the taking constituted a violation of that right. The fact of this wrong continues irrespective of any present entitlement, and the obligation to recompense is based on this wrong, rather than on the continuance of the original entitlement. In addition, if the descendants of the past perpetrators have the present property right, as the account Waldron puts forward suggests, this entitlement need not be sacrificed in order to provide monetary compensation.

Of course, such compensation is not, strictly speaking, rectification; it does not change the present to an alternative present which would have come about had the wrong not occurred. In this respect, Waldron's criticisms of Nozick's account (1974), and of its dependence on counterfactual reasoning (the prediction of outcomes if the injustice had not occurred) do not apply, because offering compensation makes no claim about what would have happened if the wrong had not occurred. I agree with Waldron that Nozick's account is untenable, but I would also point out that the difficulties in employing counterfactuals are not restricted to counterfactuals about past events, as Waldron seems to imply, but are equally prevalent in determining allocations for the future.

Repairing historic injustice is, as we have seen, a difficult business...the only thing that can trump that enterprise is an honest and committed resolve to do justice for the future, a resolve to address present circumstances in a way that respects the claims and needs of everyone. (Waldron 27) (Note 1)

It is uncertain what Waldron means by justice for the future, as a concern with future outcomes would depend upon making the kinds of judgments about human behavior to which Waldron objects in the context of past behavior. As he says, there is not only a limitation on the validity of such counterfactuals because human choices are uncertain, but because there is no determinate fact to be discovered until the decision has been made: "it is the act of choosing that has authority, not the existence as such of the chosen option." (Waldron 11) In general, we can only attend to justice in the (proximate) present, and not the more distant future.

Waldron's second principled objection is that justice must be sensitive to contemporary circumstances and conditions. While I think Waldron is basically correct about this, it is unclear why this is taken to rule out the requirement of restitution in the present. It may do so, but this must be determined on a case by case basis, and in practice I would suggest conditions are usually such that they do not remove the need for restitution. To use Waldron's example, a community on the savanna, motivated purely out of greed, attacks another group and made use of part of their watering hole. This is unjust because the encroaching group has their own watering hole which is sufficient for their needs. Later, all of the water holes except for the one now shared by both groups dries up, and consequently, Waldron claims, the imposition of the encroaching group becomes just, because they would be unable to sustain themselves without this only remaining water hole.

Contrary to Waldron's description, the harm inflicted at the earlier time, and the wrongness of it, is not eliminated by the change in circumstances, although the requirements of justice do change as a result of the altered conditions. If water were to become plentiful again, justice would require that the encroaching group offer compensation for using the other group's watering hole during the interim, perhaps by giving them access to the restored water hole they used to use, or by other means available. Compensation must be provided irrespective of whether or not the new arrivals are said to acquire property rights or entitlements to the other group's watering hole. If the drought lasted indefinitely, the compensation for the wrong inflicted prior to its onset is postponed indefinitely. The only stopping point is after decades or perhaps centuries, at which time the proof of the historic wrong is insufficient, and it can no longer be established what happened. What changes in this case is not the wrongness of the initial infringement, but what morality allows the original users of the water hole to do about the injustice inflicted on 
them. If they were to evict the trespassers during the drought, this would amount to a death sentence for the trespassers, and this would certainly be unjust. In fact, this injustice would be clearly much worse than the initial harm, which did not result in a loss of life. I suggest that this is the intuition which Waldron's case relies upon.

Despite the difficulty of determining what constitutes sufficient changes in circumstances, I agree that a reversal of fortune can affect present obligations, or rather that justice considerations in the present may override justice considerations arising from previous misdeeds. The underlying idea is that past wrongs do not justify present wrongs or harms. In other words, the moral requirement of compensation for past wrongs is not contingent, although intervening circumstances may affect present obligations.

In actual cases of indigenous land claims, the needy recipients of aid often correspond to groups which have been historically wronged. The well-being or prosperity of those charged with providing restitution and their related capacity to offer compensation is what counts, while the well-being of the wronged group is irrelevant. Nevertheless, I agree that in principal prospective compensators may be excused from fulfilling their obligation if doing so would yield injustice in the present. This situation could occur if the potential compensators are in absolute terms poor enough that such compensation would amount to a harm and injustice inflicted on them.

I have differentiated present compensation from Nozick's scheme in that it does not rely on counterfactual reasoning about what occurred or might have occurred after the historic injustice occurred, arguing that we do not need a conception of entitlement which endures over time, because the existence of the past harm is sufficient to warrant compensation. Present socio-economic conditions may alter or even remove the obligations to compensate historic injustices, but it is still morally required for the harmed party to receive compensation although the capacity of the responsible party or their descendants to provide adequate compensation may be limited or even non-existent. If compensation would amount to a harm or injustice in the present, then compensation would not be required. In this way, past harms do not justify present harms, but present conditions do not erase or deny the existence of past harms, and the claims for compensation which they support. Thus, the sensitivity of moral obligations to present circumstances does not amount to a rejection of the need for, and the validity of, compensation.

\section{Perfect and Universal Justice?}

Perhaps not only the events which transpire over time, such as the fading of memories and evidence, the acquisition of new property rights and entitlements, or changes in socio-economic conditions represent reasons against "in kind" restitution. Perhaps the very passage of time represents a factor opposed to "in kind" restitution.

It can be argued that the passage of time makes satisfaction of all justified claims impossible. If utter chaos is not to ensue, with all property rights being brought into question, it might be argued that some firm cut off date, or statute of limitations, must be established for valid land claims. How is such a date to be determined? How can an arbitrary and unfair determination be avoided, when the determination of such a cut off date will disqualify some claims, while allowing others? (Note 2) For instance, how can it be determined for which occasions the Sioux tribes, whose lands were taken or unfairly purchased at different times throughout the nineteenth century, ought to be compensated? Of course, if one goes back far enough chronologically, virtually the entire land area of the present day United States was occupied or used by indigenous peoples. (Note 3) All of these claims cannot be satisfied, and it could be concluded on these grounds that no particular claim should be honored.

One might argue along similar lines, following Jon Elster (1995) (Note 4), that restitution is inappropriate because of the irretrievable loss of so many things which are less tangible than property, but are, arguably, of even greater importance (dignity, autonomy, and, it might be added, cultural and community identity and integrity). Because of diversity and magnitude of the losses, compensation is necessarily inadequate, and therefore compensation in particular cases should not be offered.

This argument relies on two premises. The first is that if restitution is to be just, it must be universal and perfect. "Universal" means every instance of injustice is compensated. No injustice goes uncompensated. "Perfect" means each injustice which is compensated is compensated completely, that is, in exact proportion to the injustice; compensation amounts to genuine rectification of the injustice, or a restoration of conditions to what they would have been if the injustice had not occurred. The second premise is that restitution can be neither universal nor perfect. Compensation cannot be universal because of epistemic and evidential limitations, and the disruptive consequences (to put it mildly) of massive transfers of wealth and/or property, along with the infringement of present holdings and entitlements, and the arbitrariness of any cut-off date which might be imposed. Compensation cannot be perfect because of the nature of the harms imposed by, or resulting from, injustice. As Elster points out, property is only one thing which can be lost as a result of such acts. Mental or personal development can also be lost, and opportunities frustrated. 
The conclusion of the argument, then, is that since restitution necessarily fails to accomplish the end for which it was intended, to compensate for past injustices and harms, it should accordingly be avoided. I agree that restitution is necessarily, in theory and in practice, imperfect and non-universal. However this does not deprive restitution of its value as a form of approximate compensation for unjust acts, nor of the moral necessity of providing such compensation. Like other ideals, justice is not an all or nothing proposition, and it can be realized to a greater or lesser extent.

The argument demanding universal and perfect justice, or none, is consistent with a rejection of restitution even in cases where the taking can be established with certainty. If yesterday a thief stole my wallet which contained $\$ 100$, surely he should return the wallet with its money intact, in addition to suffering criminal penalties. However, according to this argument, thieves are not always caught, so we may as well not try to catch them, nor to get the stolen goods back from them. Similarly, the anger, anguish, and violation I experienced when my wallet was taken cannot be fully compensated, it cannot be taken away, even with the return of my wallet and the knowledge of the thief suffering punishment. Surely these facts do not entail that I should not be compensated by the thief, even if such compensation was limited to $\$ 100$.

In short, non-universal and imperfect justice must be accepted, and I would further argue that efforts to achieve justice are morally necessary, given our ability to meaningfully discern justice and injustice, despite the concomitant limitations on our ability to remedy or to compensate the instances of injustice which we find.

\section{4. "In Kind" Restitution}

Courts in the US have ruled that financial compensation is sufficient compensation for moral failures, such as the unjust takings of Native American lands. However, I disagree with this view, and suggest instead that when physical property was taken, the closest reasonable approximation of that property should be returned in compensation. (Note 5) There is no principled reason (unless there are competing private property rights) why compensation for moral failure should be restricted to monetary compensation. I would argue that the base line for restitution should be that of "closest approximation," from which departures must be justified.

What is required in order for restitution in kind to be warranted? It is not a restoration of conditions exactly as they were, nor a situation of universal or perfect compensation. In kind compensation remains nothing more than an approximation, not a rectification in the strict sense (a return to conditions as they were, or would have been, had the wrong not occurred). Land transfers, even if they amounted to exactly the lands which were taken (rarely if ever the case in actuality), do not compensate for the intervening time during which the group would have had opportunities to work on, improve, degrade, destroy, sell, or otherwise alter the land. The property itself is likely to have been changed, and a set of people previously in a certain relation with the land cannot have that relation restored to them.

However, the obligation to compensate for past injustices in the form of "in kind" restitution is dependent on the same constraint which I have previously discussed in the context of monetary compensation. If providing compensation in the form of land transfer or return of other property amounts to a present injustice, then it is not required. Compensation must be limited so as to avoid the commitment of further injustice. A particular instance of this in the case of in kind transfer is the possibility that individuals or groups uninvolved with the initial taking may have acquired an entitlement to the property in which case the previous injustice does not justify a repetition of the same kind of injustice. Of course, this is consistent with government purchases of private land from individuals at market prices in order to transfer the property to indigenous peoples, and with the transfer of public lands.

However, the disruption which would result from depriving people in the present of their property rights, in forced or unfair sales, constitutes a present injustice. If consensual and fair sale and transfer cannot occur, then the monetary compensation must suffice, or a partial land transfer must be accepted.

These constraints on in kind restitution do not fully address several other objections. Land restitution may have the effect of casting a cloud over private property rights. Even if only public lands are returned, there still may be a precedent which would encourage other tribes to raise new claims or to re-assert old claims. If the tribes are to be treated equally, other tribes who previously settled for money should be allowed to pursue land claims, if public land is available, or private land can be purchased. The precedent of land transfers might encourage more claims for in kind restitution, interfering with the need for closure and finality. Native land claims might affect the market and the perceived stability of property rights in large areas. (Note 6) The cession of public lands, and the costs associated with processing new or renewed claims cannot be denied.

However, I would argue that these present disadvantages do not constitute injustices if restitution is practiced subject to the prohibition of forced land sales or transfers (i.e. the violation of present property rights). They are 
instances of the costs and disruptions in kind restitution can cause, but they do not represent arguments from justice or principle. In addition, the costs of such transfers may be less than one would expect, at least in North American cases, due to the fact that many government acres, especially in the Western states of the US where government holdings are substantial, are essentially subsidized, costing the government money. Private ranchers and timber harvesters use the land and obtain government permits very cheaply. Such practices have tended to result in losses of government revenue, in a way which restitution to Native Americans would not. An economic argument using figures from the early 1980's for land restitution has been made by Russel Barsh (1982: 7) (Note 7) he concludes that land transfer would actually be cheaper than the current arrangement of government administration and assistance. This conclusion depends in part on whether or not current costs of land administration would simply be replaced by other costs resulting from land transfer (e.g. subsidy of tribal management, additional financial compensation.) Although economic arguments do not in themselves address the issue of justice, a contemporary calculation of Barsh's argument could help to dispose of a widespread objection to restitution in kind, namely its anticipated cost. It appears likely, given Barsh's calculation, that restitution may presently represent an opportunity to dispose of a costly burden, not only of managing the lands themselves, but also of administering the Bureau of Indian Affairs (BIA) and associated agencies. It may be possible to argue plausibly that such costs would not simply be replaced by other costs. If this is the case, the question becomes the question of why the government does not consider in kind restitution more frequently. (Note 8)

When particular land areas are of religious or spiritual significance, the case for in kind restitution is certainly strengthened. Often native land claims include assertions of such significance, and evidence has apparently been sufficient to convince the American Congress of the validity of such beliefs. In 1994 Congress passed amendments to the American Indian Religious Freedom Act of 1978 (Note 9) which stated that

unlike any other established religion, many traditional Native American religions are site-specific in that the Native American religions hold certain lands or natural formations to be sacred. (Note 10)

The 1978 bill and this amendment show recognition of the importance of the spiritual links between Native Americans and land, or particular geography. An additional amendment in 1994 mandated the accommodation of traditional Native American practices as much as possible and authorized legal action against parties who violate or have violated such sites. (Note 11)

The unique relation many Native American religions have expressed between the tribe and the land, and the maintenance of such beliefs to the present date, even when there has been an enforced separation from land and tradition, provide compelling reasons why lands, not just money, should be restituted in compensation for past unjust takings. It is not simply an issue of Native Americans obtaining access to this or that topographic feature at a certain time of the year. Rather, the legal arrangement must reflect the ongoing, and pervasive character of the relation between tribal cultural and religious identity, and traditional lands.

What are other potential benefits of in kind restitution? The tribes would begin to gain the actual sovereign status which they have had in theory since the earliest contact with American settlers. Self-government and territorial integrity are crucial aspects of tribal autonomy. Greater tribal autonomy may represent the only viable path to economic (and, I would add, political) development for native peoples of North America. In addition, it may be the only way in which the integrity and cultural uniqueness of the tribes will be preserved. Experiments with assimilationist policies have historically been unsuccessful, if not disastrous. (Note 12) While the most serious and widespread attempt at assimilation has subside further steps have to be taken in order to create real autonomy. Control and title over greater, and spiritually/culturally important land areas, is one essential means for attaining this end.

Insofar as a precedent is established by a transfer of lands to Native American groups, it is a precedent which ought to be encouraged, not rejected. Namely, that unjust takings of land by the government warrant, and will receive, restitution, even when restitution is inconvenient and politically unpopular, in ways which financial compensation is not. Such a gesture is important on consequentialist grounds in that it helps to dispel the appearance that, in the eyes of the government at least, takings and ill treatment can be justified on racial or ethnic grounds, or otherwise deemed acceptable. Restitution in kind, while it does not "undo" past wrongs, results in the requisite public gesture more effectively than any financial compensation can.

\section{The Struggle for the Black Hills}

The majority of Sioux tribes, living primarily on reservations in North and South Dakota and Nebraska, have attempted to gain compensation, or in kind restitution, for lands which were taken by the United States beginning in 1877. Many other native American land claims have been settled in the last fifty years, often without significant in kind restitution. The Sioux claim for the Black Hills of South Dakota, however, is still alive, formerly in the 
Courts, and recently in Congress. I will provide an overview of the history of the Sioux land case, from the taking itself through the 1980 Supreme Court ruling that the tribes were entitled to compensation in the amount of $\$ 117$ million. The purpose of examining this case is to illustrate not only the appropriateness of restitution, but also the conditions under which restitution in kind (in this case, a land transfer) is called for. In addition, I aim to argue for this policy action in this and analagous cases.

Before 1805, Sioux tribes occupied and hunted buffalo and other game in a large portion of the Midwest, ranging from Nebraska to Minnesota. Sometimes, in pursuit of the buffalo herds, they would go as far north as Canada, or as far south as Texas. The first official contact with the new American republic was with Lewis and Clark in 1804. From 1805 to 1868 , the Sioux tribes were party to thirty-three treaties, some of which also affected other Indian nations. Generally these were treaties of peace and friendship, and tribes were compensated in various ways (clothing, blankets, food, annuities, even guns) for cession of lands. In 1825, the US government designated much of the traditional Sioux midwestern range as "Permanent Indian Country", on the belief, following one of the earliest explorers of the territory, Major Stephen Long, who thought the territory a "Great American Desert," "unfit for civilization." (Lazarus, 1991)

In 1851, a treaty was signed at Fort Laramie, in the present state of Nebraska, outlining for the Sioux nation including all of the present state of South Dakota, as well as parts of Nebraska, Wyoming, North Dakota and Montana. The US Senate later added amendments to the treaty which were rejected by the Sioux, and the treaty was never ratified. The result of this treaty's failure was the Powder River War of 1866-67. It ended with another treaty at Fort Laramie, on April 29, 1868. (Note 13) This established the Great Sioux reservation, which included half of South Dakota (everything west of the Mississippi) and extensive hunting rights in large parts of North Dakota, Wyoming, Colorado, Kansas, and Nebraska. Both parties pledged peace, and the US government promised to prosecute US citizens who harmed tribal members. (Note 14) No settlement was permitted on the reservation, which was set aside for the "absolute and undisturbed use of the Indians." (Note 15) The Indians relinquished claim to other areas outside the reservation, and the treaty stipulated that lands could not be ceded back to the government without three quarters of all adult males' consent. (Note 16) The United States promised to provide agricultural supplies and to allot land for individual Indian families to farm. Rations were provided, along with clothing and the promise of annuities for several decades.

In 1874, at the request of the Secretary of War, Lieutenant Colonel George Custer conducted an expedition into the Sioux held Black Hills, an area along the western border of present day South Dakota, which resulted in the discovery (or rather, confirmation) of gold. Prior to the expedition, and perhaps even at the time of the 1868 Laramie treaty, the United States was aware of potential mineral wealth; the tribes were also aware of this potential. After the expedition, fortune seekers' invaded the Black Hills. Initially, the government made some efforts, sometimes involving military force, to suppress these attempts. However, according to the Supreme Court's account, President Grant believed that "such resistance only increased their desire and complicated the troubles." (Note 17) The orders to permit the gold seekers' invasion were to be quietly carried out, and the President's decision to allow the miners to continue, to remain "confidential." (Lazarus, 1991: 94) (Note 18) In 1875, seven months after Custer's expedition, the Grant administration decided to acquire the Black Hills; the Allison Commission was appointed for this end. The tribe asked for $\$ 70$ million, but the government only offered $\$ 6$ million, and the negotiations collapsed.

That winter, the Commissioner of Indian Affairs ordered the Sioux hunters, who had gone north to hunt (as they had the right to do under Article 16 of the 1868 treaty) to return to the southern part of the reservation. Weather conditions made return impossible, and the Seventh Cavalry under Custer attempted a surprise attack on the hunters, in early 1876. A humiliating defeat of the US Cavalry resulted. Two hundred fifty-nine US troops, including Custer, were killed, at what came to be known as the Battle of Little Big Horn. However, the army soon thereafter prevailed at Wounded Knee, confining both the tribes involved in the Battle, as well as thousands of uninvolved Sioux who had stayed away from the fighting, on their agencies (Lazarus, 1991). Partly in response to the Battle of Little Big Horn, Congress ordered rations cut off until the tribes agreed to cession.

Unable to hunt, because their weapons and horses had been confiscated, and starving, ten percent of the Sioux signed an agreement at Red Cloud Agency, Nebraska, on September 26, 1876, ceding the Black Hills in exchange for rations, which were to be provided until they became self-sufficient. Despite the fact the 1868 treaty required three-quarters of the adult males to agree to any ceding of land, an act ratified in Congress on February 28, 1877 formalized the taking of the Black Hills. In addition, Congress dissolved hunting rights outside the 900,000 acres which the tribes were allotted in the northern part of the previous reservation. The tribes would continue to get annuities from the 1868 treaty, along with rations and agricultural assistance. Children were obliged to attend English speaking school if they were to receive rations. A plan was made for tribal representatives to visit other 
territories to select Indian land to find a "permanent home", where they would remove to within one year of selection and agreement. The treaty stipulated that the Indians agree to "submit themselves to such beneficent plans as the Government may provide for them in the selection of a country suitable for a permanent home, where they may live like white men." (Note 19)

As Alexis de Tocqueville observed some fifty years earlier in regard to other tribes:

The expulsion of the Indians often takes place at the present day in a regular and, as it were, a legal manner. When the European population begins to approach the limit of the desert inhabited by a savage tribe, the government of the United States usually sends forward envoys...Half convinced and half-compelled, they [the Indians] go to uninhabited deserts, where the importunate whites will not let them remain ten years in peace. In this manner do the Americans obtain, at a very low price, whole provinces, which the richest sovereigns of Europe could not purchase. (1987, 340-341)

In 1887, the national General Allotment Act, or Dawes Act, stipulated that plots of about 160 acres were to be given to each Indian head of household. Some of the lands were kept in trust by the government or leased to private non-Indians. The Dawes Act had the effect of weakening tribal unity by recognizing individuals rather than tribes. (Note 20) In addition, it led to large areas of collectively held land being disposed of in parcels. In the case of the Sioux, lands were sold before survey and allotment, rather than being allotted before being opened for settlement, as the Act stipulated. Although Sioux families were given twice the minimum required acreage, 9 million acres were lost when the surplus land was put on the market. Due to the poverty of the Indians, and the resulting economic necessity of selling the allotted land, speculators and other non-Indians obtained $80 \%$ of the allotment land on some reservations. Allotment caused the reservations to hold lands in an irregular "checkerboard" pattern, with some land held in trust for Indians, and for non-Indians who had fee patents. (Lawson, 1982) This pattern resulted in inefficiency, as it introduced obstacles to cultivation and other productive uses. (Note 21)

In 1889, the US confiscated half of the remaining Indian land and divided the other half into five reservations. In the next twenty years, there were other seizures of land carried out by legislative or executive order. In 1928, the Meriam Report recommended abolishment of allotment and urged improvement of social services. During this period, some attempts were made under the reformist Indian Commission John Collier to halt alienation of Indian lands, and more generally to provide opportunities for economic development. Other changes accompanied the FDR's New Deal, such as allowing the practice of native ceremonies. In 1936, a program of restoring some Native American lands began, although the additions were relatively minor. (Note 22) In 1944, an Army Corps of Engineers water development program was undertaken in the Missouri Basin. The Pick Sloan Plan, as it was known, resulted in the flooding of 202,000 acres of Sioux land. By the Act of September 2, 1958, 55,000 acres were removed from the Standing Rock reservation for a dam project. (Note 23) Although the tribes were given some financial compensation, they did not have the option to refuse the project. Some tribal protests were mounted, to no avail. Altogether, the three Pick Sloan projects reduced the total land base of five Sioux reservations by about 6 percent. (Note 24) From 1954 to 1960, the United States followed a policy of "termination." This was an unsuccessful attempt to end the tribal character of Indian society and the special relationship between the tribes and the government. Federal protection of tribes was to be withdrawn. While the policy may have been well intentioned, the final results for the tribes were very poor, and the loss in social services harmful. When individual tribal members migrated into the cities, as the policy of termination encouraged them to, they often ended up in urban ghettoes, unable to secure employment and other necessities.

In the legal realm, prior to 1946, when the Indian Claims Commission was formed, there was no legal venue for the pursuit of treaty-based claims against the government. The Court of Claims, which had been founded in 1863, was not permitted to accept suits based on treaties and the doctrine of sovereign immunity. However, the Court of Claims could accept such land claim cases if congressional authorization were obtained by means of direct petition. Between 1836 and 1946, Congress authorized 142 such suits. (Note 25)

Sioux lobbying efforts started soon after the Black Hills were taken. The tribal governments obtained the requisite jurisdictional act from Congress in 1920, allowing them to file a claim in the Court of Claims. (Note 26) The Sioux filed a claim in the Court in 1923. Finally, in 1942, the Court issued a ruling. The Court dismissed the claim on the basis that Congress could unilaterally abrogate treaties, and that, for this reason, the Fifth Amendment did not apply. (Note 27)

The tribes were unable to take further legal action until the passage, in 1946, of the Indian Claims Commission Act. (Note 28) The Act provided for "claims based upon fair and honorable dealings that are not recognized by any existing rule of law or equity. (Note 29) Thus, the ICC was, at least in theory, open to moral claims which went beyond the scope of claims heard in previous cases in the Court of Claims. Eight hundred claims were filed in the 
first five years after creation of the ICC. In 1950, the Sioux claim was submitted to the ICC. In 1978, the Indian Claims Commission held that the government must pay just compensation for the taking, and that the price paid to the tribe for the 1868 cession was "unconscionable." (Note 30) The tribes were awarded almost $\$ 50$ million, in payment for the total value of the extinguished Sioux interests, and the Court ruled that the government could not deduct potential offsets for rations and other services. (Note 31)

After the US appealed the ruling, the appellate body, the Court of Claims held, in its 1979 decision, that the government was liable for a fifth amendment taking, on the grounds that Congress had not made a "good faith effort" to pay the full value of the land, plus interest. The value plus interest was calculated as $\$ 105$ million, the largest settlement for a native American land claim. (Note 32) Only two tribes, the Crow Creek and the Santee, were willing to accept the cash settlement. The other six tribes, led by the Oglala, opted to seek return of land, in addition to money. (Note 33) The decision to seek land restitution represented a departure from the usual attitude of most Indian nations towards settlement. Like many other tribes, the Sioux had shared the widespread acceptance of the fundamental premise of claims law; namely, that monetary compensation was, and maybe should be, the only possible relief for takings. (Newton, 1992)

In addition to pursuing legal remedies and lobbying Congress, the tribes took action in the international arena. The American Indian Movement (AIM), led by William Means, attempted to bring attention to the case of the Black Hills through the United Nations, where the tribe has had official NGO status. Mr. Means has repeatedly brought the case to the attention of the United Nations Commission on Human Rights, contending that cash compensation violates international law. On February 28, 1973, AIM initiated the "occupation" of Wounded Knee (where, in 1890, the US Cavalry killed 300 unarmed Sioux.) The "occupation" was held in protest over the management of the reserve by the Bureau of Indian Affairs (BIA). Although the village is on the Pine Ridge reservation, government agents surrounded the camp, and started a siege that lasted seventy-one days. Two Indians were killed and many were wounded. The Government agreed to hold an inquiry to re-examine the 1868 treaty, with little consequence. After the siege at Wounded Knee, forty AIM members and sympathizers were found dead at Pine Ridge "in suspicious circumstances" between 1973 and 1976. (Burger, 1987)

Since the 1979 decision, there have been a number of legal actions regarding the Sioux land claim. The United States appealed the 1979 decision of the Court of Claims to the Supreme Court, which affirmed the judgment. (Note 34) The settlement amounted at this time to more than $\$ 117$ million ( $\$ 17.5$ million at the time of the taking and 5\% interest subsequently). The egregiousness of the case did not go unnoticed, as Justice Blackmun stated: "A more ripe and rank case of dishonorable dealings will never, in all probability, be found in our history. . . " On July 23, 1980, \$105 million was transferred from the Treasury to the Department of the Interior, and invested for the tribes. The Department of the Interior maintains that compensatory damages were, in effect, paid at that time. In contrast to the Supreme Court's ruling, the BIA holds that the Sioux lost the Black Hills in 1877 by Congressional action, and that only Congress, not the courts, can provide compensation. Since the transfer of funds, there have been two central obstacles to disbursement. One is the bureaucratic task of determining who the beneficiaries should be; there are approximately 50,000 potential beneficiaries. More importantly, the Oglala Sioux of the Pine Ridge reservation rejected the award, along with other tribes who agreed, to varying degrees, with the Oglala's stand.

Although a variety of economic and developmental indicators highlight the economic need of the Oglala Sioux on Pine Ridge and in Shannon County - where most of the reservations of the Oglala Sioux are located, the need for economic aid does not by itself call for in kind restitution as persuasively as the relation of the Sioux tribes to the land, and the specific religious and spiritual significance of the Black Hills to the Sioux tribes. Numerous legends and cultural practice of the Sioux reflect a conception of respect for the earth. Central to the philosophy and to the cosmogony is the notion that the earth, called Maka, is the "first and real mother of all life." In the legend of "otokahe Ekta", humans are depicted as one of her four children. (Note 35) The legend suggests not only human interrelatedness with the other animal inhabitants of the earth, but, as the maternal character of Maka suggests, the intimate relationship between humans and the earth itself A care-taking relationship followed from the view of this relationship. Evidence is found in agricultural practices, such as the requirement that lands be allowed to rest and regenerate for at least seven years between uses. The specific justification for this policy was that "the earth should have only good memories of habitation by the two legged." (Note 36) In this way, it appears that consciousness was attributed to the land, and that this belief was sufficient to inform behavior. Black Elk, an Oglala Sioux elder stated: "the Earth is your Grandmother and Mother, and she is Sacred. Every step that is taken upon her should be as a prayer," (qtd. Boyles, 1990) attesting to the personally experienced relationship with the earth. There is an important and strong identification not just with land in general, but with the Black Hills in particular. This is suggested by the tribal saying "As long as you keep the Black Hills, you will be Lakota." Many Sioux believe that 
they emerged from particular sites in the Black Hills. (Note 37) According to Reginald Bird Horse, the Vice President of the Black Hills Sioux Nation Treaty Council:

There are thousands of us who believe as our ancestors before us have believed, that Paha Sapa (the Black Hills) is very, very holy. All of the Black Hills is like a temple to us. There are certain places in Paha Sapa like Wind Cave and Mahto Tipi (Devils Tower to some) that are emergence sites for some of our people. (Note 38)

The entire Black Hills region thus appears to be regarded as a spiritual center. This status follows not from topographic features alone, but also from proximity and position relative to stars, constellations, and other celestial bodies. Constellations played an essential part of the religious tradition of the Lakota. Indeed, the tradition incorporated astronomical and topographic features in a unique manner. At different times of year, the tribes were required to go to certain parts of the Black Hills for ceremonies and worship services. (Note 39) These sites included Harney Peak and Pe Sla, a meadow in the Black Hills, and Mato Tipila, or Devil's Tower. The Black Hills was, and apparently continues to be understood as "the microcosmic hoop out of which, annually, new life is born on earth." (Note 40) In Lakota theology, life was thought to occur within an eternally recurring cycle of time, space, matter and spirit centered on the Black Hills. (Note 41) Rather than remaining remote doctrine, there is some evidence that this theological perspective was and continues to be reflected in personal terms. (Note 42)

\section{The Black Hills and in Kind Restitution}

In 1986, Senator Bill Bradley of New Jersey unsuccessfully proposed a bill (Note 43) which called for the reconveyance of 1.3 million acres (of the 7 million taken in 1877) to the Sioux tribes; these lands included portions of the Black Hills, in the westernmost part of South Dakota. Some but not all federally owned lands in the region would be returned in fee simple, in contrast to their present status as lands held in trust by the federal government. The federal ownership of the lands to be returned obviates one of the most powerful potential arguments against in kind restitution, namely that such restitution would violate claims made by private owners who were given title to the land after the government taking. Of course, neighboring non-Indian landowners would nevertheless be affected by the proposed transfer; they could be affected by the assignment of water rights or hunting rights, for instance. In addition, the Sioux would be granted the right of first refusal to adjacent lands sold by private owners.

The Bradley Bill exempted the Mount Rushmore National Memorial from the land transfer. The images of various presidents are carved into the face of Mt. Rushmore, which is located in the Black Hills. Mt. Rushmore would be left open for tourist access, as would other portions of the region, which would be called a "Sioux Park." Traditional religious or ceremonial sites would be excluded from public access "to the extent necessary to preserve their primary religious uses and integrity." (Note 44) Any lands in the park designated by the Sioux as a wildlife and wilderness sanctuary could also be excluded. Land use was regulated to some extent. Lands were to "remain in the state of use or development" to which they had been committed at the time the Act became effective. There was no specific restriction on sale. (Note 45) The Bill stated that the land should be "used in accordance with the traditional principle of 'respect for the earth'." (Note 46) This principle presumably refers to management policies which would serve to maintain, or, when necessary, to restore the ecological integrity of the land, with respect to animal and plant life in particular. Portions of the territory in the Black Hills which were previously under the jurisdiction of the US Forest Service, would become Black Hills Sioux Forest.

The second major element of the bill stipulated that the tribes would still receive the monies awarded by the Supreme Court in 1980. Rather than serving to extinguish title, the money would be given in payment for the loss of the use of the Black Hills since the taking; the payment would also be intended as reimbursement for gold removed from the region: 36 million ounces of gold were removed by one company alone, the Homestake Mine.

There are some compelling reasons why in kind restitution of the Black Hills should be enacted by the federal government. These reasons include the traditional tribal connection with the geography of the Black Hills, a connection and relationship permeated with religious and cultural significance. I have suggested that legal title is the only way in which this relationship can occupy the central role in the tribal communities of the Sioux which it needs to occupy if the tribes are to realize greater autonomy and self-determination. Other more tangible goods, such as economic development, depend in a different way on an increased land base, and the expansion of entrepreneurial opportunities.

While there are not, I take it, insurmountable theoretical or philosophical barriers to this outcome, there are some serious empirical concerns, which must be dealt with on the level of policy. Concerns can be raised over the issue of tourist access, and this is a legitimate and serious issue, as are environmental concerns about the management of the Black Hills region once the land has been transferred. The issue of tourist access is, I think, a particularly acute issue because, more than environmental concerns and possible associated legislative restrictions, the entry of 
non-Indians into the Black Hills can be particularly threatening to such a nascent cultural community. In addition, notwithstanding the apparent tribal commitment to the Black Hills and to its local ecology, serious consideration should be given to different means of ensuring the territorial and environmental integrity of the region.

An additional question is who should receive the land and the other benefits which would accompany it. I would claim that since Sioux lands were held collectively at the time of the taking, and Sioux society was and remains of a distinctively tribal character, it is appropriate for the compensation to be awarded to the collectivity, rather than to individuals per se. However, I am reluctant to accept that, had the policy of termination been effective, and the tribes were dissolved, leaving only disaggregated individuals, that such individuals would not be entitled to compensation, although the case for in kind restitution would be weaker in this case. Even if the direct beneficiaries of restitution are to be the tribes, the question of who the individual members of the tribes are still enters the picture. For instance, is it enough to have one grandparent, or one parent, and to have lived off of the reservation for most or all of one's life, etc? Since there is undeniably a core group of Native Americans who descend from the wronged group, there clearly is a group to whom restitution is owed. In addition, many tribal members and their families have lived on the reservation for all or most of their lives.

Although the Bradley bill only required a portion of the lands to be returned to the tribes, it is an example of the political compromise which can come near to satisfying the moral obligation for in kind compensation for which I have argued.

\section{Conclusion}

In sections 1-4, I have claimed that despite arguments to the contrary, compensation for historic injustices, such as the taking or unfair purchase of land and other properties, is morally obligatory. Such compensation neither depends upon objectionable counterfactual reasoning (found in Nozick's account) nor a concept of property rights or entitlements which lasts into the present. I have argued that the existence of the past injustice is insufficient and that compensation for it must approximate as closely as possible a return of what was taken, in addition to whatever other compensation is warranted (for example, for prior use or resource exploitation.)

In sections 5 and 6 , I have sought to illustrate one case where in kind restitution seems appropriate, due not only to the merits of the case itself, but also to the fact that much of the land which can be transferred is not privately owned and would not consequently violate any present property rights or yield further injustice in the present.

Finally it should be noted that whatever value in kind restitution may have, the deeply political character of the process of securing a land transfer is blindingly evident in light of the history of the struggle for the Black Hills, from the time of the initial taking to the present. Until change occurs on the political level, more abstract considerations will be of little moment.

\section{References}

Barsh, R. L. (1982). Indian Claims Policy in the United States. NDL Rev., 58, 7-8.

Boyles, K. L. (1990). Saving Sacred Sites: The 1989 Proposed Amendment to the American Indian Religious Freedom Act. Cornell L. Rev., 76, 1117-1149.

Burger, J. (1987). Report from the Frontier: The State of the World's Indigenous Peoples. London and New Jersey: Zed Books Ltd.

Deloria, Jr., V., \& Lytle, C. M. (1983). American Indians, American Justice. Austin, TX: University of Texas Press.

Elster, J. (1995). On Doing What One Can: An Argument Against Post-Communist Restitution and Retribution. In N. Kritz (Ed.), Transitional Justice: How Emerging Democracies Reckon with Former Regimes: Volume 1 (pp. 566-568). Washington, D.C.: United States Institute of Peace Press.

Kymlicka, W. (1991). Liberalism, Community and Culture. Oxford: Clarendon Press.

Lawson, M. (1982). Damned Indians: The Pick Sloan Plan and the Missouri River Sioux, 1944-1980. Norman, OK: University of Oklahoma Press.

Lazarus, E. (1991). Black Hills, White Justice. New York, NY: Harper Collins.

Newton, N. J. (1982). The Judicial Role in Fifth Amendment Takings of Indian Land: An Analysis of the Sioux Nation Rule. Or. L. Rev., 61, 245.

Newton, N. J. (1992). Indian Claims in the Courts of the Conqueror. The Am. UL Rev., 41, 753. 
Newton, N. J. (1993). Compensation, Reparation \& Restitution: Indian Property Claims in the US. Ga. L. Rev., 28, 453-468.

Nozick, R. (1974). Anarchy, State and Utopia. New York: Basic Books.

Tocqueville, A. de. (1987). Democracy in America (Vol. I). New York: Knopf.

Waldron, J. (1992). Superseding Historic Injustices. Ethics, 103, 4-28. http://dx.doi.org/10.1086/293468

Cases

Sioux Tribe vs. United States, 97 CT. Cl. 613 (1942), 318 U.S. 789 (1943)

Sioux Tribe of Indians vs. United States, 42 Indian Cl. Commission 257, 257 (1978)

Sioux Nation vs. United States, 601 F. 2d, 1173 (Ct. Cl. 1979)

United States vs. Sioux Nation, 448 US 371 (1980)

\section{Legislation}

An Act Authorizing the Sioux Tribe of Indians to Submit Claims to the Court of Claim, 1920

The American Indian Religious Freedom Act of 1978

American Indian Religious Freedom Act Amendments of 1994

\section{US Congressional Testimony}

Congressional testimony regarding S. 1453, introduced July 17, 1985, 99th Congress, 1 st session.

- Black Elk, Charlotte A., transl., Black Hills Steering Committee testimony on "Respect for the Earth"

- Blue Thunder, David quoted in statement of James Howard, a member of Congress from New Jersey, USA

- Darcy, Cindy, Friends Committee of National Legislation

- Goodman, Donald and Stanley Red Bird, "Lakota Star Knowledge and the Black Hills"

- Jewett, Keith, Cheyenne River Sioux Nation representative

- $\quad$ Standing Rock Sioux Tribal Council, Resolution No. 232-85

\section{Notes}

Note 1. Presumably Waldron means to exclude present claims about past wrongs, 27.

Note 2. In fact, the determination of a cut-off date necessitates identifying in advance who will be affected by the cut-off point. As Newton points out in "Compensation, Reparation \& (and) Restitution: Indian Property Claims in the US," Ga. L. Rev. 28 (1993), 453, if the compensation cut off is too early, it may require compensating expropriators.

Note 3. This claim, along with any other ancient Indian land claims, could be questioned on the grounds that Native Americans have historically not possessed the traditionally Anglo-European conception of land title and ownership. In response, the conception of aboriginal title, title from "time immemorial," should be noted. This concept, in contrast to the concept of specific and recognized title, has gained widespread acceptance in native land claim cases.

Note 4. Jon Elster, "On Doing What One Can: An Argument Against Post-Communist Restitution and Retribution," excerpted in Kritz, Neil, Volume I of Transitional Justice: How Emerging Democracies Reckon with Former Regimes, (Washington, D.C., United States Institute of Peace Press, 1995) 566-568. In the section that follows I am extending Elster's argument, which applies explicitly only to the case of post communist restitution.

Note 5. Of course, sometimes there is no close approximation, as when Vietnam War veterans exposed to Agent Orange had children who suffered birth defects.

Note 6. When aboriginal land claims in Australia were first receiving serious consideration by the courts, there was considerable consternation that such claims might result in the return of property, including downtown Sydney, to the aboriginals.

Note 7. Barsh observes that about $87 \%$ of the estate is for commercial leasing and public access (national forests and grazing lands); he notes that the total historical investment is a little over $\$ 3$ trillion, less than the annual federal contribution to Indian administration and reservation transfer payments. The United States owns, he reports, 
$32.6 \%$ of all land nationwide, and the cumulative cost of the estate is $\$ 10.60$ per acre, with an annual income of a little over $\$ 4$ per acre. Barsh concludes that reconveyance of public lands would be a far less costly alternative to financial and administrative assistance. Russel Lawrence Barsh, "Indian Claims Policy in the United States," NDL Rev. 58, (1982) 7 .

Note 8 . One answer to this question is that restitution is politically unpopular, due not only to widespread attitudes of citizens, but also due to the interests of governmental agencies.

Note 9. The American Indian Religious Freedom Act of 1978 declared that it was the policy of the United States: "to protect and preserve for American Indians their inherent right of freedom to believe, express, and exercise the traditional religions of the American Indians...including but not limited to access to sites, use and possession of sacred objects and the freedom to worship through ceremonial and traditional rites." "The American Indian Religious Freedom Act of 1978," 8.

Note 10. "American Indian Religious Freedom Act Amendments of 1994," H.R. 4155, 103d Congress, 2d Session, introduced March 24, 1994, 3-4.

Note 11. Loc cit.

Note 12. See also Will Kymlicka, in Liberalism, Community and Culture (Oxford: Clarendon Press, 1991), 176: "Facilitating assimilation not only doesn't work as well as protecting cultural membership, it often doesn't work at all." Also, Kymlicka has suggested "cultural membership seems crucial to personal agency and development," 176.

Note 13. The treaty involved the following tribes: Brule, Oglala, Miniconju, Yanktonai, Hunkpapa, Blackfeet, Cuthead, Two Kettle, Sans Arcs, Santee and Arapahoe.

Note 14. Article 11.

Note 15. Article 1.

Note 16. Article 2.

Note 17. Quoted in Congressional testimony regarding S. 1453, introduced July 17, 1985, 99th Congress, 1st session.

Note 18. Nell Jessup Newton, "The Judicial Role in Fifth Amendment Takings of Indian Land: An Analysis of the Sioux Nation Rule," Or. L. Rev. 61 (1982), 245. At the end of his two terms, Grant reflected on the question of why the treaty was not enforced. He rationalized that "the avarice of the white man [was] such that an effort to remove the miners would only [have resulted] in the desertion of the bulk of the troops sent to remove them."

Note 19. Article 4.

Note 20. Michael Lawson, Damned Indians: The Pick Sloan Plan and the Missouri River Sioux, 1944-1980 (Norman, OK: University of Oklahoma Press, 1982), 33-34.

Note 21. As Newton notes in "Compensation," allotments were generally lost in several different ways: 1.) judicial sales arising from the new owner's failure to pay property taxes, 2.) outright sales to speculators, and 3.) government programs which removed restrictions on alienation, in order to encourage Indians to sell their land.

Note 22. There were orders to restore or add lands to the reservations again in 1938 and 1975.

Note 23. P.L. 85-915 18, ctd. in Lawson, 55.

Note 24. Loc cit.

Note 25. Keith Jewett, Cheyenne River Sioux Nation representative, Congressional testimony regarding S. 1453, introduced July 17, 1985, 99th Congress, 1st session, 128.

Note 26. An Act Authorizing the Sioux Tribe of Indians to Submit Claims to the Court of Claim, Act of June 3, 1920, Pub. L. No. 237, 41 Stat. 738.

Note 27. Sioux Tribe vs. United States, 97 CT. Cl. 613 (1942), cert. denied, 318 U.S. 789 (1943)

Note 28. ch. 950, 60 Stat. 1049, 25 U.S.S. 70-70v (1976 \& Supp. II 1978.)

Note 29. clause V of the ICC Act of 1946, Pub. L. No 726, CH. 9592 (5), 60 Stat., 1049, 1054.

Note 30. Sioux Tribe of Indians v. United States, 42 Indian Cl. Commission 257, 257 (1978). 
Note 31. Such offsets would have totaled more than the claim, according to Vine Deloria, Jr., and Clifford M. Lytle, American Indians, American Justice (Austin, TX: University of Texas Press, 1983), 53. The government appealed the ruling on offsets to the Court of Claims, which ruled that evidence of such offsets was inadmissible.

Note 32. Sioux Nation v. United States, 601 F.2d, 1173 (Ct. Cl. 1979) The test applied in this case has been questioned by Newton, who observes that the Court of Claims focused on whether the government intended consideration to be a fair equivalent, not whether or not it was, in objective terms ("Judicial", 256-258).

Note 33. The Oglala tribe is noted as refusing the money in Nell Jessup Newton (1992; 761). Newton notes that acceptance of the funds could have constituted extinguishment of title.

Note 34. United States vs. Sioux Nation, 448 US 371 (1980)

Note 35. "The first child is Taku Xkan Xkan - what moves and grows. The second child is Warupa - moves high by spreading out. Her third child is Wahu Topa - moves on four legs. The fourth child is her special child, Wahu Numpa moves on two legs, He is named Mato - I am different, set apart, and symbolizes wisdom." Black Hills Steering Committee testimony on "Respect for the Earth", translated by Charlotte A. Black Elk, and excerpted in Congressional testimony regarding S. 1453, introduced July 17, 1985, 99th Congress, 1st session, 198.

Note 36. Op cit., 203.

Note 37. Prepared statement of Cindy Darcy of the Friends Committee of National Legislation, quoted in Congressional testimony regarding S. 1453, introduced July 17, 1985, $99^{\text {th }}$ Congress, 1 st session, 251.

Note 38. Op cit., 229. Elsewhere in the same transcript, Resolution No. 232-85 of the Standing Rock Sioux Tribal Council similarly attests to the religious significance of the Black Hills and the region's indispensability to the exercise of Sioux religion. Ronald Goodman and Stanley Red Bird, "Lakota Star Knowledge and the Black Hills" excerpted in Congressional testimony regarding S. 1453, introduced July 17, 1985, 99th Congress, 1st session, 215-218.

Note 39. A three year "Lakota Star Project" performed under the auspices of Sante Gleska College on the Rosebud Reservation provides evidence substantiating the view that an "ancient and sacred relationship exists between the Lakota people, the star, the sun and the Black Hills."

Note 40. Congressional testimony regarding S. 1453, introduced July 17, 1985, 99th Congress, 1st session, 218.

Note 41. Loc cit.

Note 42. As David Blue Thunder, a deceased Sioux holy man on the Rosebud Sioux Reservation remarked: "The Black Hills is the heart of our home and the home of our heart". Quoted in statement of James Howard, a member of Congress from New Jersey, Congressional testimony regarding S. 1453, introduced July 17, 1985, 99th Congress, 1st session, 255.

Note 43. S. 1453, proposed in the 99th Congress, 1st session.

Note 44. Section 11, paragraph b., page 18.

Note 45 . Article 15 states that the rights to enter into various kinds of agreements are reserved by the tribes.

Note 46. Section 12, paragraph a.

\section{Copyrights}

Copyright for this article is retained by the author(s), with first publication rights granted to the journal.

This is an open-access article distributed under the terms and conditions of the Creative Commons Attribution license (http://creativecommons.org/licenses/by/3.0/). 